\title{
Correction to: Chloride content of solutions used for regional citrate anticoagulation might be responsible for blunting correction of metabolic acidosis during continuous venovenous hemofiltration
}

Rita Jacobs, Patrick M. Honore*, Marc Diltoer and Herbert D. Spapen

Correction to: BMC Nephrol

https://doi.org/10.1186/s12882-016-0334-3

Following publication of the original article [1], we have been notified that the approved number by the Ethical Committee was given incorrectly. In the section "Methods" stated that: The Central Ethical Committee of the University Hospital approved the study protocol (B.U.N. 143201318818), this number is incorrect and should be expressed as follows: B.U.N. 143201318819.

Published online: 24 March 2020

\section{Reference}

1. Jacobs, et al. Chloride content of solutions used for regional citrate

anticoagulation might be responsible for blunting correction of metabolic acidosis during continuous venovenous hemofiltration. BMC Nephrol. 2016; 17:119. https://doi.org/10.1186/s12882-016-0334-3.

The original article can be found online at https://doi.org/10.1186/s12882016-0334-3

* Correspondence: Patrick.Honore@az.vub.ac.be

Intensive Care Department, Universitair Ziekenhuis Brussel, Vrije Universiteit Brussel, 1090 Brussels, Belgium

(c) The Author(s). 2020 Open Access This article is licensed under a Creative Commons Attribution 4.0 International License, which permits use, sharing, adaptation, distribution and reproduction in any medium or format, as long as you give appropriate credit to the original author(s) and the source, provide a link to the Creative Commons licence, and indicate if changes were made. The images or other third party material in this article are included in the article's Creative Commons licence, unless indicated otherwise in a credit line to the material. If material is not included in the article's Creative Commons licence and your intended use is not permitted by statutory regulation or exceeds the permitted use, you will need to obtain permission directly from the copyright holder. To view a copy of this licence, visit http://creativecommons.org/licenses/by/4.0/ The Creative Commons Public Domain Dedication waiver (http://creativecommons.org/publicdomain/zero/1.0/) applies to the data made available in this article, unless otherwise stated in a credit line to the data. 